\title{
(Re)Conceptualising Unfree Labour: Local Labour Control Regimes and Constraints on Workers' Freedoms
}

\author{
Judy Fudge, McMaster University, Canada ${ }^{1}$
}

\begin{abstract}
Disputes over the meaning of human trafficking, forced labour and modern slavery have both provoked and coincided with a reinvigorated debate in academic and policy literatures about how to conceptualise unfree labour. This article traces the contours of the debate over free and unfree labour, identifying its key stakes as the debate has developed and paying particular attention to recent interventions. It begins by identifying a problem common to both canonical liberal and Marxian approaches to the free/unfree labour distinction, which is to fetishise the labour market. It then discusses the consensus that is emerging across disciplines and in leading international organisations that labour unfreedom in contemporary capitalism is best conceptualised as a continuum rather than a binary, highlighting recent disciplinary-specific contributions. It argues that the metaphor of a continuum of labour unfreedom obscures more than it illuminates. Drawing upon the growing body of literature that advocates a multifaceted approach to labour unfreedom, this article argues that a robust concept of local labour control regime does a much better job of capturing the complex mix of consent and coercion involved in extracting value from labour power than the idea of a continuum of labour unfreedom.
\end{abstract}

\section{KEY WORDS}

unfree labour; migration; capitalism; exploitation; labour control

\section{Introduction}

Disputes over the meaning of human trafficking, forced labour and modern slavery have coincided with a reinvigorated debate about how to conceptualise unfree labour, a phenomenon that has attracted increasing attention as neo-liberal labour regimes, best exemplified by global supply chains, have become embedded across the globe. Although conducted in different idioms or registers - the first involves legal and policy questions, while the latter tends to be academic and theoretical - and, thus, the debates are not congruent, they tend to overlap and intersect. Significantly, the way that unfree labour is conceptualised informs the kinds of strategies and policies that are advocated to deal with the range of its contemporary manifestations.

The fault line over the dispute about how to conceptualise unfree labour is whether or not the key institutions of capitalist labour markets - private property, contract and wage labour - are seen as resulting in work arrangements that are regarded as consensual and fair or coercive and exploitative. At the crux of the discussion of free and unfree labour are notions of consent, coercion and exploitation. Anthropologists, development scholars, historians, geographers, socio-

\footnotetext{
${ }^{1}$ I would like to thank the fellows, Director and staff at the 2019 Annual Work and Human Life Cycle in Global History (re:work) conference in 2018 for their helpful comments on the first draft of this article, which I presented there, and the very helpful comments of the Journal's anonymous reviewers.
} 
legal researchers, feminists, international political economists and migration scholars have added nuance to what has become a highly stylised debate between orthodox liberal and Marxian political economists. Researchers tend to emphasise different features or processes depending upon their discipline, epistemological frame and political commitments.

Recently, a consensus across a range of disciplines has begun to converge around conceiving of labour unfreedom (Strauss and Fudge, 2014; LeBaron, 2015; Bernards, 2017; Fraser, 2018), labour exploitation (Skrivankova, 2010) and labour compulsion (Gordon, 2018) as a continuum. This approach was initially adopted by researchers who, influenced by Marxian political economy, wanted to highlight the ontological and epistemological similarities, rather than categorical differences, between different forms of labour and labour regimes in contemporary capitalism, and to draw attention to the structural causes, as opposed to individual pathologies, that produce labour unfreedom. In particular, researchers in this genre use unfree labour as a lens to analyse the impact of neo-liberal capitalism on the incorporation of labour and labour power. By contrast, a liberal approach does not treat the lack of economic options available to workers as either coercive or exploitative, and instead focuses on extra-economic coercion or force. However, there has been a recent shift in international discourse from a criminal law paradigm for addressing modern slavery to a development-oriented approach, as exemplified by target 8.7 (eradicating modern slavery) in the United Nations Sustainable Development goals. This shift suggests that conceptualising labour unfreedom as continuum requiring a range of different strategies, including criminal law and positive obligations on business to take responsibility for unfree labour in their supply chains, is gaining ground (Plant, 2017; MGrath and Watson, 2018).

In the next section, the article traces the contours of the debate over free and unfree labour, paying particular attention to recent interventions and the stakes of the debate. In the middle section, I show how, despite the consensus that is emerging in the critical literature around the view that labour unfreedom is best regarded as a continuum, the metaphor of a continuum obscures more than it reveals. Building on the literature that develops a multifaceted approach to labour unfreedom, I argue in the fourth section that the concept "labour control" does a much better job at capturing the complex mix of consent and coercion involved in extracting value from labour power than the idea of a continuum of unfreedom. I elaborate the notion of a local labour control regime, and show that it can be used to analyse how constraints on workers' freedoms within and beyond the labour process are activated or imposed by a range of actors in capital's search for profit. I conclude by reflecting on the significance of substituting a robust notion of labour control for the idea of a continuum of unfreedom in order to better understand contemporary capitalism.

\section{The Persistence of Unfree Labour under Capitalism}

Trafficking for the purpose of labour exploitation, forced labour and modern slavery have attracted renewed regulatory attention from international institutions and states over the past two decades (O'Connell-Davidson, 2015; Bunting and Quirk, 2017). Anti-slavery and migrant rights activist networks are mobilising public opinion against a range of different forms of unfree labour in the global economy, and corporations and philanthrocapitalists have jumped on the bandwagon (Chuang, 2015; McGrath and Watson, 2018). Academics across a range of disciplines have turned their attention to exploring the dynamics behind and different manifestations of unfree labour, and it has become a burgeoning field of study across a wide variety of disciplines.

The persistence and proliferation of unfree forms of labour across developed, emerging and developing countries has been linked to the different aspects of contemporary globalisation - 
dispossession through war, ecological degradation and structural adjustment policies; transnational criminal activity; state corruption and the breakdown of the rule of law; international migration; and neo-liberal capitalism (Bales, 1999; Morgan and Olsen, 2014; Peksen, Blanton and Blanton, 2017; Castles, 2018; Fraser 2018; Gordon, 2018). The blurring of boundaries between free and unfree labour perturbs both orthodox liberal and Marxian accounts of the emergence and development of capitalist labour markets (Mezzadra and Neilson, 2013: 100).

The free/unfree labour distinction originates in the political economy literature, which has sought since the eighteenth century to understand (and define) linkages between political and social power and economic systems of production and reproduction. Influenced by Hegel's association of the freedom of the subject with the ability to engage in the exchange of property (which included, for Hegel, the subject's own productive capacity), Marx defined labour power as a commodity (Brass, 2011). Marx (1990: 49) characterised the buying and selling of labour power in capitalist societies as a process wherein "both buyer and seller of a commodity, say of labour power, are constrained only by their free will. They contract as free agents, and the agreement they come to is but the form in which they give legal expression to their common will". The freedom to circulate in the labour market and to sell their labour power to a number of different employers was the hallmark of the "free" labour of wage earners. By contrast, "the slave is the property of a particular master; the worker must indeed sell himself to capital, but not to any particular capitalist, and so within certain limitations he may choose to sell himself to whomever he wishes; and he may also change his master" (Marx, 1990: 50). But, as Bernards (2017: 945) notes, "free labour for Marx is not defined by the voluntary nature of work" but instead "by a historical shift in the forms of coercion deployed in the exploitation of labour". Wage labourers were doubly "free" - free both from personal dependence upon a master and from access to the means of subsistence.

By contrast, liberal political economists and neo-classical economists are concerned with the voluntariness of the exchange. Within classical liberal political economy, the distinction between unfree and free labour is ontological. Free labour is an individual condition of self-proprietorship. Neoclassical economists understand buyers and sellers of labour power as utility-maximising agents operating in a frictionless world (Friedman, 1962; Hayek, 1973; Smith, 1983).

Kevin Bales (2004; 2012a), the most influential proponent of the global initiative to eradicate modern slavery, exemplifies the liberal approach. He claims that "slavery is, first and foremost a state of being - not a legal definition, an analytical framework, or a legal construct" (Bales 2012a: 360). Slavery "is the control of one person (the slave) by another (the slaveholder or slaveholders)", which "transfers agency, freedom of movement, access to the body, and labor and its product and benefits to the slaveholder" (Bales, 2012b: 370). The hallmark of slavery is the "radical diminution of free will" and loss of personal liberty (Bales, 2012b: 370). Modern slavery is an aberration in a free market, either an historical remnant of a pre-modern society or a crime.

Orthodox Marxist and liberal political economists have different conceptions of the labour market; the former see it as the outcome of violent dispossession and the locus of economic compulsion, whereas the latter regard contractual wage labour as the apogee of consent and freedom (Friedman, 1962: 10). Both, however, draw a clear distinction between free and unfree labour, and associate each with distinct modes of production (Tomlins, 2010: 9). Free labour accompanies capitalist forms of economic organisation which, through its expansion, will wipe out forms of unfree labour such as indenture and chattel slavery.

Thus, a key concern has been how to understand the coexistence of unfree labour with the expansion of capitalism. Writing within a Marxian political economy framework, Robert Miles 
(1987) regarded the capital/wage-labour relation as the essential and constitutive feature of capitalist modes of production. However, he argued that free wage labour was compatible with other forms of labour within a social formation. He emphasised the articulation of pre-capitalist forms of unfree labour, such as bonded labour, for example, to provide a supply of labour for emerging capitalist production regimes. He also stressed the coercive power of the state in reproducing unfree labour. Similarly, Robin Cohen (1987: 17) explained that, although specific forms of labour control such as chattel slavery, serfdom, debt bondage, apprentice labour, child labour, and indentured and contract labour are associated with certain labour regimes, it is perfectly possible for a variety of different forms of labour control to co-exist at a specific time and place.

Miles and Cohen led the way in using unfree labour to explicate the relationship between capitalism and migration. Unfree labourers, such as peasants or bonded labourers, were compelled to migrate as a result of changes to agricultural production, especially capitalisation and commodification, which resulted in their dispossession from the land. States structure different modes of migrant labour incorporation through immigration controls that restrict the ability of migrant workers to freely circulate in the receiving country's labour market (Satzewich, 1991). This approach draws upon an understanding of freedom that is rooted in the idea of the formal legal freedom to circulate in the labour market. It also provides the conceptual space to link processes of racialisation to unfree forms of labour and their persistence under capitalism (Miles, 1987; Smith and Choudry, 2016). How racialisation is used to legitimate the use of unfree labour in capitalism, an economic system in which free wage labour is the ideal, draws on the insight that discursive constructions of ascriptive characteristics such as race, gender and ethnicity are used to create differences that are essential to managing the technical and social division of labour (Corrigan, 1977: 449).

While there is general agreement among critical political economists across disciplines that capitalism is compatible with forms of unfree labour, the vexing problems are both how to conceptualise the distinction between unfree and free labour and how to account for unfree labour's continuing existence under advanced capitalism. A recent and incisive overview of the debate over free and unfree labour from a global history perspective identifies Free and Unfree Labour: The Debate Continues, a collection edited by Tom Brass and Marcel Van Der Linden (1997), as embodying a key divergence in how the distinction between free and unfree labour was conceptualised within literature that did not consider wage labour to be the apotheosis of the "free" choice of workers (De Vito, Schiel and Van Rossum, 2018). ${ }^{2}$ On the one hand, scholars like Brass continued to insist on the ontological distinction between free and unfree labour in terms of whether labour power is commodified and sold by the worker or whether the worker (labour) is sold (Brass, 1997: 60; Brass, 2014: 293). On the other hand, there are scholars, mostly drawn from labour history, who challenge the dichotomy between free and unfree labour, pointing to a range of different coercive practices existing in a particular place and time, and emphasising the background legal rules of contract and property that are critical for institutionalising a labour market (Lucassen, 1997; Steinfeld and Engerman, 1997; Tomlins, 2010).

It is important to consider what is at stake in Brass's (2014: 293) claim that unfree and free labour are ontologically distinct. He regards the wage worker to be the distinctive revolutionary political subject under capitalism since only the proletariat has the potential to engage in a class struggle that can result in systemic transformation. Unfree labour denotes the loss of the ability

\footnotetext{
${ }^{2}$ In this article I will not review the recent historical literature on the unfree/free labour distinction, as De Vito et al. (2018) have produced a comprehensive discussion of it from a global labour history perspective.
} 
to commodify one's own labour power, which is, according to Brass, a disciplining process that cheapens the cost of labour power for capitalists. Thus, the substitution of unfree labour for free labour is a process of de-proletarianisation imposed by capitalists as a means of halting the formation of a proletarian class consciousness (Brass, 1999: 12-14, 300). Brass's commitment to revolutionary Marxian theory leads him to reject approaches that consider unfree and free labour to be points on a continuum as embracing neoclassical economists' commitment to methodological individualism (Brass, 2014: 293-294).

By contrast, historians such as Steinfeld and Engerman (1997) argue that it is not possible to maintain a rigid epistemological or analytic distinction between free and unfree labour. They claim that unfree labour that is coerced through the threat or use of physical violence or stateadministered legal compulsion is not different in kind from the economic compulsion that produces free labour. This is because economic compulsion is the product of a prior distribution of "legal rights, legal privileges and legal powers, which places one person in a position to force another person to choose among disagreeable alternatives, just as 'legal' compulsion and, in most systems of coerced labor, 'physical' compulsion do" (Steinfeld and Engerman, 1997: 120). Under capitalism, the economic coercion that gives rise to free wage labour is an "artifact of the law" (Steinfeld, 2001: 20; see also Banaji, 2003: 71). Other historians, like Lucassen (1997), Van der Linden (1997) and Tomlins (2010), would keep the distinction between different types of labour - for example, between unfree dependent labour (slavery, servitude), free dependent labour (wage labour), and free independent labour (small farm holding) - and accept that these different forms can be combined under a single mode of production.

\section{A Continuum of Labour Unfreedom under Capitalism}

Historical work has revealed the co-existence and "entanglement" of different forms of free and unfree labour (De Vito et al., 2018). Development scholars also insist upon "the fluidity of actually occurring unfreedoms" that characterise diverse forms of labour in the contemporary capitalist global economy (Lerche, 2007: 447). Together this research has contributed to the shift from treating unfree and free labour as a binary to regarding freedom and unfreedom as a continuum. However, it is not yet clear what different researchers mean by the idea of continuum. Thus, it is helpful to tease out the conceptual work it performs for different researchers and in different contexts.

Researchers deploying the notion of a continuum of labour unfreedom refer either to degrees of "coercion/compulsion" or to "exploitation", although sometimes these terms are used interchangeably (LeBaron, 2015, for instance). Moreover, different researchers sometimes have different audiences - policy makers or academic researchers. These features of the literature make it hard to pin down with any precision the various conceptions of a "continuum" of unfreedom.

The International Labour Organization (ILO) adopts the simplest idea of a continuum. Operating from a legal and policy perspective, it conceptualises work arrangements as existing along a continuum with free choice is at one end and coercion, the threat of coercion and deception at the opposite end.

It may be useful to consider a range of possible situations with, at one end, slavery and slavery-like practices and, at the other end, situations of freely chosen employment. In between the two extremes, there are a variety of employment relationships in which the element of free choice by 
the worker begins at least to be mitigated or constrained, and can eventually be cast into doubt (ILO, 2009: 8-9). ${ }^{3}$

The single axis for distinguishing between forced and free labour is free and informed choice.

Some researchers have been critical of the ILO's approach to forced labour. They argue that the ILO has framed forced labour as an illicit practice carried out by unscrupulous employers rather than a predictable outcome of the way that supply and production chains are organised and liability is limited to direct contractual relations (Lerche, 2007; Rogaly, 2008; Phillips and Mieres, 2015; Bernards, 2017). The effect of this framing is, they claim, to "cocoon" forced labour from the broader processes of neo-liberal capitalism (Lerche, 2007). Instead, these critics emphasise the importance of understanding the role that legal and social relations of property and debt play in the incorporation of forced labour into transnational global value chains.

In his conception of the continuum of labour unfreedom, legal historian Robert Steinfeld also focuses on choice, but he expands his conception of coercion to include liberal legal institutions such as private property in determining individual choice sets:

Rather than view compulsion in labor relations in terms of a binary opposition divided by type of pressure, it seems more plausible to think in terms of a combined scale of pressures, legal, physical, economic, social, psychological, all running along a continuum from severe to mild, rather than falling into a binary opposition. This would not only help us to understand that the various types of pressure employed in eliciting labor are commensurable, operating in surprisingly similar ways at bottom, but also to see that the real focus of inquiry should be upon the choice sets with which individuals are confronted as they make their decisions about conducting their lives, and the ways in which these choice sets may be altered by changing legal arrangements (Steinfeld, 2009: 12).

While this approach is an advance over those like the ILO's, which simply bracket out the background legal rules and institutions, Steinfeld's focus on the "choice sets" confronting individuals tends to flatten out the different modalities or forms of labour unfreedom.

Instead of beginning with choice sets, some Marxian critics start from the premise that all labour under capitalism is unfree, and they claim that different forms of coercion - economic, legal-juridical and physical - can result in a continuum of unfreedom (Cruz, 2018; Gordon, 2018). Gordon (2018: 8) argues that analyses that isolate "legally unfree labour", such as temporary migrant workers, from a broader understanding of unfreedom rooted in the reproduction of capitalist social relations have the potential to cede "political ground to the liberal ideological claim that so-called free wage labour ... is an important exemplar of freedom achieved under capitalism". While this argument can serve as an important caution, the underlying analysis of labour unfreedom and the dynamics of capitalism upon which it rests are too general. Other than some general references to austerity or neo-liberalism (Cruz, 2018: 87; Gordon, 2018: 11), there is little discussion of the dynamics of contemporary global capitalism and how it plays out at different sites and different scales for specific populations. More helpful is the literature that links neo-liberal capitalism to different forms of unfreedom and the discourses that support them (Sharma, 2006; LeBaron, 2015; Fraser, 2018).

While most of the literature that adopts a continuum approach to unfree labour focuses on degrees or types of compulsion, some of it concentrates on exploitation. Historically the ILO has

\footnotetext{
${ }^{3}$ The 1930 Forced Labour Convention defines forced labour as "all work or service which is exacted from any person under the menace of any penalty and for which the said person has not offered himself voluntarily" (ILO, 1930: Article 1).
} 
focused on coercive means, whereas exploitation typically refers to outcomes (Plant, 2017: 425). Recently, the term "exploitation" has begun to figure in ILO documents, likely because the term is used in the United Nation's Human Trafficking Protocol in order to identify illegitimate purposes that make up one of the elements in the crime of trafficking. ${ }^{4}$ The ILO has not specified the criteria for identifying outcomes that are exploitative (Plant, 2007: 429). A discussion paper prepared for the World Bank distinguishes between consensual exploitation and nonconsensual exploitation; the latter includes unfree forms of labour such as forced labour, human trafficking and slavery (Koettl, 2009). It also recognises that there may be economic forms of coercion in which individuals allow themselves to be exploited because they have no option. But, according to the World Bank, these kinds of situations are limited to monopsonistic markets in which employers enjoy an inelastic labour supply and thus vastly superior bargaining power. Some commentators define exploitation as the breach of legal norms pertaining to employment (Allain et al., 2013), whereas others identify the exclusion of vulnerable workers from labour standards available to other workers as exploitative (Mantouvalou, 2018).

By contrast, analyses who believe that the background rules of contract and property constrain choices are much more willing to consider most forms of consensual employment to be exploitative, since exploitation is a characteristic of structural and not individual relationships. For Marx, exploitation is the difference in the wage paid to the worker, which covers the socially necessary cost of reproduction, and the surplus value generated by the worker's labour (Fraser, 2018: 3; Gordon, 2018). There is no need for individual coercion or mistreatment as the employment relationship is seen as exploitative per se.

It is very easy for discussions of labour unfreedom to become mired in definitional debates about the meaning of choice, coercion and exploitation. ${ }^{5}$ One way of avoiding being side-tracked down a philosophical rabbit hole is both to historicise the continuum and to link it to the broader political economy. By historicising the continuum, I mean recognising that the terms "exploitation" and "coercion" figure as historically specific judgements that reflect the kinds of arrangements and relationship that have come to be accepted as natural by marking what falls outside the norm (Bernards, 2017: 945). Consent, coercion and exploitation are contested concepts, and an historical approach enables us to identify the contours of the contestation at particular times and places. Moreover, connecting the continuum to the broader political economy helps us to identify the different kinds of constraints operating in a specific context, and whether these constraints are accepted as legitimate or contested as unacceptable. For example, in an influential policy paper, Klara Skrivankova (2010) opened up the kinds of constraints that could be seen as contributing to exploitation beyond coercion and deception, by linking her idea of exploitation to the existing regulatory framework. She regards exploitation as the outcome of "external and individual circumstances" that include "legal framework, labour market functions and failures, crime, migration, individual agency and status" (Skrivankova, 2010: 16). This approach links exploitation to regulation and to status hierarchies.

The identification of migration controls as contributing to exploitation resonates with the

\footnotetext{
${ }^{4}$ The Human Trafficking Protocol defines trafficking in terms of three elements: (1) the act, which includes the recruitment, transportation, transfer or harbouring of persons; (2) the means, which includes the threat or use of force or other forms of coercion, fraud, abuse of power, and (3) the purpose, which is exploitation. It then goes on to list different examples of exploitation including slavery, forced labour and prostitution (UN General Assembly, 2000: Article 3(a)).

${ }^{5}$ Part of the problem is that some researchers adopt a methodologically individualist approach to determining the existence of exploitation or coercion, while others look at the background social conditions as creating structural conditions of exploitation or coercion. Some shift between the two.
} 
work of sociologists who point to immigration controls that restrict the ability of temporary migrant workers to freely circulate in the labour market, typically by linking lawful residence in the receiving country to an employment relationship with a specific employer (Cohen, 1987; Miles, 1987; Satzewich, 1991; Basok, 2002). Immigration controls are conceptualised as a form of politico-legal compulsion that is organised through the national state system and operates alongside market-dependent compulsion to sell one's own labour power (Smith, 2015; Smith and Choudry, 2016). Sharma argues:

[It is] important to understand that freedom and its antithesis are both legal-juridical and social and ideological categories, categories fundamentally informed though ideologies of nationalism, racism and sexism. It is these every day or 'banal' forms of discrimination that organizes the legitimacy for their legal coercive consequences (Sharma, 2006: 69).

The commodification of all labour power takes place in legal-juridical as well as economic space, and, since labour is always embodied (Banaji, 2003), this process harnesses ideologies of race and gender.

Racialisation is one of the discourses of differences that underpin why some workers are free, while others are unfree (Miller, 2012; 255). Sharma (2006: 72) and Fraser (2018:7) emphasise the extent to which the notion of free, waged citizen workers is both defined in opposition to and depends upon the "other" - the unfree worker - and how the divide between the two is often racialised. Several researchers demonstrate how discourses and ideologies of racialisation and gender imbue different legal-political categories of unfree workers and give them social currency (Bakan and Stasiluis, 2012; Smith, 2015; Smith and Choudry 2016).

Feminist political economists stress the mutual articulation of production and social reproduction, and the centrality of class and other relations of subordination and social hierarchy, such as gender, race and, later, citizenship. The contribution they make to understanding the relationship between free and unfree labour has been both to demonstrate the significance of women's "unfree" domestic work for the emergence of industrial capitalism and to illustrate how forms of labour control at the workplace draw on patriarchal norms that render women unfree.

Women's unwaged and not directly waged labour was central to the development of capitalist market relations (Frederici 2004). The devaluation of women's labour and its confinement to the household was a critical part of the long evolution of industrial capitalism in the Global North (Seccombe, 1992: 44). Feminist political theorists like Carol Pateman (1988) have emphasised the unfree nature of women's domestic work, while sociologist Evelyn Nakano Glenn (2002) shows how in the United States gendered forms of unfree labour were also racialised. Critical development scholars stress the extent to which patriarchal norms in social reproduction and the wider society contribute to how women's labour power is commodified (Kelly, 2009; Mezzadri, 2016). Alessandra Mezzadri (2016: 1884) shows how "patriarchal norms" are deployed in the Indian garment sector "to maximize processes of surplus extraction across different labour processes" by creating a highly gendered sweatshop regime, in which labour discipline is achieved not only in the factory but also in the household and larger society. She claims that the Indian women garment workers are simultaneously free in the Marxian sense and subject to patriarchal unfreedom that extends beyond the household to the workplace (Mezzadri, 2016: 1892).

Several researchers have added complexity to the notion of a continuum by adding another axis. Recent work in geography has sought to illustrate how unfreedom is integral to the organisation of contemporary production regimes in the private economy and to provide a 
spatially grounded account of how unfreedom is produced (Rogaly, 2008: Strauss and McGrath, 2017). McGrath (2013) explicitly adopts a multidimensional approach to understanding labour unfreedom, and she adds the dimension of degradation in the employment relationship, which links conditions such as exposure to workplace hazards and the intensification of work, to that of restricted freedom (see also Yea and Chok, 2018). This emphasis on degradation of work corresponds to recent research in anthropology that advocates an approach to conceptualising unfree labour that "links property and relations of domination and production to the qualitative experience of exploitative work" (Calvão, 2016: 458). Strauss and Fudge (2014: 15) also add a second axis to the continuum approach to unfreedom - labour market polarisation and the dimensions, such as pay and income and job security, that make work precarious work (see also De Vito et al., 2018: 21-22).

Increasingly, research on unfree labour directs attention to the political-legal context and the regulatory framework, re-centring the role of states as agents involved in creating conditions restrictive immigration regimes, deregulated labour markets and unrestrained financial markets in which labour unfreedom and exploitation can flourish (Strauss and Fudge, 2014; Fudge, 2018; LeBaron and Phillips, 2018). Most promising for both understanding unfree labour and developing strategies to combat it is research that is explicit that the continuum of labour unfreedom is being used as a heuristic to emphasise governance while simultaneously stressing the need to develop the links between social reproduction, production and accumulation.

LeBaron provides the most comprehensive account of how to evaluate and assess labour unfreedom. She considers:

(1) the systemic compulsions and forms of coercion that underpin people's entrance into labor and their (in)ability to leave the labor contract; (2) the social relations surrounding experiences in the sphere of circulation; (3) the conditions involved in, and their experience of, the labor process itself (LeBaron, 2015: 14).

This heuristic adds an important dimension to the more familiar approach to studying coercion, which focuses on entry into the labour relationship, the actual labour process, and exit from the labour process (Steinfeld and Engerman, 1997: 109-113), by attending to how social reproduction and social hierarchies, make some workers - women, racialised workers and migrants - more vulnerable to a variety of forms of compulsion and coercion. With three axes of (un)freedom, LeBaron is able to examine the continuum of exploitation and unfreedom at different scales and levels of governance. Thus, she is able to link macro processes, such as global changes in land ownership, to meso-level changes in migration regimes and, in turn, see how these regimes influence the actual conditions that migrant workers experience.

\section{Constraints on Workers' Freedoms and Local Labour Control Regimes}

Adding different axes or dimensions to the idea of a continuum of labour unfreedom has the advantage of capturing the complexity of the practices, processes, institutions and actors that combine to make labour unfree. Some conceptions are attentive to different sites of unfreedom (social reproduction/production) and to different forms (legal/political, physical/economic, for instance). Researchers have also added a spatial and scalar approach to understanding labour unfreedom (McGrath, 2013; LeBaron, 2015). While these conceptions are a vast improvement on simple binaries or continuums that are constructed around the axis of choice, the problem is that positioning unfree and free labour as endpoints of a continuum reinforces the idea that 
coercion/consent and freedom/unfreedom are antithetical dyads. In an attempt to move away from notions of unfreedom that conceptualise it as a condition or status of the worker, McGrath and Strauss (2015) consider unfreedom in labour relations in an attempt to bring power, both in the workplace and labour market, into the analysis. This relational approach is an improvement over focusing on the worker's status, but I suggest that instead of focusing on unfreedom, it is more helpful to concentrate on control and to draw upon labour process theory, which has long recognised that labour control and the extraction of value is a complex and contradictory process involving both coercion and consent (Burawoy, 1979). Moreover, researchers, primarily in economic geography, have developed the idea of local labour control regimes, which connects labour process theory to the broader political economy and shows how labour control is created and exercised in spaces, such as the household, that exist beyond the site of production (Jonas, 1996; Baglioni, 2018).

The concept of a local labour control regime is a useful way to analyse how workers' freedoms are constrained in the process of capital's attempt to extract value from workers' capacity to work. The idea of unfree labour, understood as an inversion of free wage labour, "is not analytically productive in understanding the particular historical dynamics" of what are often profoundly distinctive arrangements (Miller, 2012: 16). By contrast, however idealised, the meaning of "free" wage labour is clear. It refers to the capacity of workers to enter and exit a labour contract freely, and by the mid-twentieth century included political and social freedoms (Marshall, 1950). Labour process theory has focused on how capital extracts surplus value at the work site through mechanisms of discipline and control that combine coercion and consent and provoke different forms of resistance (Newsome et al., 2015). Focusing on labour control still allows for the analytic distinction between the sale of labour and labour power, which is essential for understanding the origins of industrial capitalism, while at the same time appreciating that "labour-power is never disembodied, what employers buy when they 'buy' 'labour-power' is command over the use of workers' bodies and their persons" (Banaji, 2003: 70).

Recent research connects labour process theory, which focuses on the point of production, to broader spaces of control. Social reproduction and patriarchal norms in the household as well as immigration controls can result in distinctive labour control regimes (Mezzadri, 2016; Polanco, 2016). Economic geographers are developing the idea of the local labour control regime "as an analytic device that dialectically links workplaces to broader local and global dynamics thereby offering a complex, multilevel understanding of the labour process" (Baglioni, 2018: 113).

Jonas (1996: 329) defines a local labour control regime as "an historically contingent and territorially embedded set of mechanisms which co-ordinate time-space reciprocities between production work, consumption and labour reproduction within a local labour market". The regime is dynamic set of social relations and power structures that are constantly reproduced, contested and/or transformed by forces operating at a variety of scales. What a local labour control regime does is provide a "relatively stable institutional environment for capital accumulation" in a system that is prone to periodic crises (Jonas, 1996: 329). Jonas develops what Lefebvre (1991) saw as a tension between place (the local needs of particular capital) and space (the global and expanding nature of capitalist production relations). This spatial contradiction is resolved by attempts to control workers' freedom, which is understood in terms of access to the labour market, consumer goods and to means of social reproduction (Lefebvre, 1991: 330). Particular capitals that are sensitive to local contexts develop labour control strategies that limit the freedom of labour in these social spaces, as well as at the site of production (Lefebvre, 1991: 335).

Adapting Jonas's idea of a local labour control regime, Baglioni (2018: 114) “frames labour 
control as the interplay between labour exploitation and labour disciplining" that are shaped at different scales (global, national and local). She uses exploitation in the Marxian sense as "the production of value in excess of labour remuneration", and defines labour disciplining as the ongoing attempt to mitigate, prevent, manage and contain the conflict inherent in the subordination of labour in the production process (Baglioni, 2018: 114). But instead of occurring simply at the point of production, Baglioni, like Jonas, argues that labour disciplining also occurs in social spaces such as the household. Drawing on her study of exploitation and disciplining in Senegalese export horticulture, Baglioni refers to the spatial and social disciplining of labour, illustrating the first in terms of outsourcing and the latter by reference to gender.

I propose adding the dimension of commodification to Baglioni's conception of labour control in order to capture more fully the range of mechanisms and the variety of social spaces through which labour control, however provisionally, is secured. Mezzadri (2016: 1881) distinguishes between commodification (the process by which "classes" of labour with different freedoms are created) and exploitation (the extraction of value). Commodification is distinct from, but integrally connected to, labour exploitation and labour disciplining; what the idea of commodification does is try to account for how different workers are incorporated into the labour process. Mezzadri explains how the unpaid social reproductive work of women in northern India was critical for the ability of men to migrate to work in garment factories. If labour control is understood as the interplay between commodification, exploitation and disciplining, the idea of a local labour control regime can be used to reveal how the constraints on workers' ability to commodify their labour power - such as, for example, visa controls that restrict migrant workers' circulation in the receiving country's labour market or patriarchal norms that restrict women's mobility in their local community - provide local capital with disciplinary power over workers to ensure that value is extracted. Mechanisms of labour control can be created in the transnational space by linking receiving countries' immigration controls to sending countries' remittance-led development policies. Polanco (2016: 1342), for instance, shows how between 2007 and 2014 Tim Hortons, one of Canada's largest quick-food chains, used a precarious migrant labour regime, which dangled the promise of permanent residence status in Canada under an employer nomination scheme in its outlets and franchises in western Canadian provinces to recruit workers from the Philippines. The spatial disciplining of labour can occur in many ways, and it can activate a range of social differences in its cause.

By combining commodification, exploitation and disciplining, the notion of a local labour control regime provides an analytical framework and the conceptual tools needed to examine the multi-scalar economic, social and political dynamics that result in the incorporation of different constraints on workers' freedom. Understanding how local labour control regimes emerge also requires attention to how the political, economic and cultural vectors of accumulation and social reproduction converge at a specific time and place to mobilise existing hierarchies and social relations. It is a mid-level concept that is responsive to "historical and geographic" struggles over the constraints on working peoples' freedoms (Chari, 2018: 21).

\section{Conclusion}

The purpose of this article was to identify some of the key stakes in the contemporary debate over how to conceptualise and grapple with free and unfree forms of labour. These are the extent to which capitalist labour markets are seen as restricting labour freedom and the extent to which forms of domination other than capitalism are seen as contributing towards labour unfreedom. I suggest moving away from the terminology of labour unfreedom because it lacks analytic value, 
and is too profligate descriptively. The idea of a continuum of unfreedom simply does not account for modalities of control, relations of power and the interests involved. For example, trafficked migrants who are coerced do not choose to cross borders to work. By contrast, migrant workers who participate in managed migration programmes or who avail themselves of "migrant smugglers" are choosing, despite real conditions of constraint experienced by many of them, to cross borders in order to work. Many authorised temporary migrant workers are not free to circulate in the host country labour market unless they obtain permission from a hoststate official to obtain employment with a new employer. However, the constraints on their freedom are of a different kind than that of migrant or resident workers who are bonded by debt to an employer who may injure or harm them or their family members. Undocumented migrants are "free" to circulate in the host country's labour market at the peril of criminalisation and exploitation. Some of these forms of unfreedom are illegal but tolerated, such as private recruiters who charge fees to migrants in violation of national laws. Others, like human traffickers, are illegal and strenuously policed. Still others, such as temporary labour migration programmes that tie a worker's migrant status to their continued employment with a specific employer, are perfectly lawful but may be conducive to employers engaging in a range of unlawful employment practices. There are salient differences between different forms of labour control, and a range of different actors are involved - from states, agencies that act as recruiters and brokers, employers, criminal organisations and families.

For these reasons, I argue that the concept of a local labour control regime provides a better basis for developing an account of how a wide variety of constraints on workers' freedoms are mobilised in order to extract value from labour power. Conceiving labour control as the interplay between labour commodification, labour exploitation and labour disciplining directs attention to the range of different social processes, relations and spaces in which coercion and consent play out. Understanding the relationship between local labour control regimes and broader processes of accumulation and multi-scalar political projects is critical for developing effective and robust strategies to combat specific constraints on workers' freedom and for envisaging sustainable collective challenges to subordination.

\section{REFERENCES}

Alain, J., A. Crane, G. LeBaron and L. Behabahani (2013) Forced Labour's Business Models and Supply Chains. London: Joseph Rowntree Foundation.

Bakan A. and D. Stasiulis (2012) The Political-economy of Migrant Live-in Caregivers: A Case of Unfree Labour? In Legislated Inequality: Temporary Labour Migration in Canada, edited by P. Lenard and C. Straehle. Montreal and Kingston: McGill-Queen's University Press.

Baglioni, E. (2018) Labour Control and the Labour Question in Global Production Networks: Exploitation and Disciplining in Senegalese Export Horticulture. Journal of Economic Geography, 18(1): 111-137.

Bales, K. (1999) Disposable People: New Slavery in the Global Economy. Berkeley, CA: University of California Press.

Bales, K. (2012a) Professor Kevin Bale's Reponse to Professor Orlando Patterson. In The Legal Understanding of Slavery, edited by J. Allain. Oxford: Oxford University Press.

Bales, K. (2012b) Slavery in its Contemporary Manifestations. In The Legal Understanding of Slavery, edited by J. Allain. Oxford: Oxford University Press.

Banaji, J. (2003) The Fictions of Free Labour: Contract, Coercion, and So-Called Unfree Labour. Historical Materialism, 11(3): 69-95. 
Basok, T. (2002) Tortillas and Tomatoes: Transmigrant Mexican Harvesters in Canada. Montreal: McGill-Queen's University Press.

Bernards, N. (2017) The Global Politics of Forced Labour. Globalizations, 14(6), 944-957.

Brass, T. (1997) Some Observations on Unfree Labour, Capitalist Restructuring, and Deproletarianization. In Free and Unfree Labour: The Debate Continues, edited by T. Brass and M. van der Linden. Berlin: Lang.

Brass, T. (1999) Towards a Comparative Political Economy of Unfree Labour: Case Studies and Debates. London and New York: Routledge.

Brass, T. (2011) Unfree Labour as Primitive Accumulation? Capital \& Class, 35(1): 23-38.

Brass, T. (2014) Modern Capitalism and Unfree Labor: The Unsaying of Marxism. Science \& Society, 78(3): 288-311.

Bunting, A. and J. Quirk, J. (2017) Contemporary Slavery: Popular Rhetoric and Political Practice. Vancouver: University of British Columbia Press.

Burawoy, M. (1979) Manufacturing Consent: Changes in the Labor Process Under Monopoly Capitalism. Chicago, IL: Chicago University Press.

Calvão, F. (2016) Unfree Labor. Annual Review of Anthropology. 45: 451-467.

Castles, S. (2018) Unfree Labour, Migration and Social Transformation in Neoliberal Capitalism. In Work Out of Place, edited by M. Sakar. Oldenbourg: De Gruyter.

Chari. S. (2018) Commentary on "From Exploitation to Expropriation: Geographies of Racialization in Historic Capitalism. Economic Geography, 94(1): 18-22.

Chuang, J. (2015) Giving as Governance? Philanthrocapitalism and Modern-Day Slavery Abolitionism. U.C.L.A. Law Review, 62: 1516-1556.

Cohen, R. (1987) The New Helots: Migrants in the International Division of Labour. Hants: Gower.

Corrigan, P. (1977) Feudal Relics or Capitalist Monuments? Notes on the Sociology of Unfree Labour. Sociology, 11(3): 435-463.

Cruz, K. (2018) Beyond Liberalism: Marxist Feminism, Migrant Sex Work, and Labour Unfreedom. Feminist Legal Studies, 26(1): 65-92.

De Vito, C., J. Schiel and M. van Rossum (2018) From Slavery to Precarity: Labour History Revisited and Beyond. Journal of Social History, under review.

Federici, S. (2004) Caliban and the Witch: Women, the Body and Primitive Accumulation. Brooklyn, NY: Automedia.

Fraser, N. (2018) Roepke Lecture in Economic Geography - From Exploitation to Expropriation: Historic Geographies of Racialized Capitalism. Economic Geography, 94(1): 1-17.

Friedman M. (1962) Capitalism and Freedom. Chicago, IL: University of Chicago Press.

Fudge, J. (2018) Modern Slavery, Unfree Labour and the Labour Market: The Social Dynamics of Legal Characterization. Social and Legal Studies, 24(4): 414-434.

Gordon, T. (2018) Capitalism, Neoliberalism, and Unfree Labour. Critical Sociology, https://doi.org/10.1177/0896920518763936.

Hayek, F. (1973) Law, Legislation, and Liberty. Chicago, IL: University of Chicago Press.

International Labour Organization (ILO) (1930) Convention Concerning Forced or Compulsory Labour, 1 May 1932, 39 UNTS 55, art 2.

International Labour Organization (ILO) (2009) The Cost of Coercion. Report of the Director-General, 98th Session, International Labour Conference, Report I(B). Geneva: ILO.

Jonas, A. (1996) Local Labour Control Regimes: Uneven Development and the Social Regulation of Production. Regional Studies, 30: 323-338. 
Kelly, P. (2009) From Global Production Networks to Global Reproduction Networks: Households, Migration and Production Networks in Cavite, Philippines. Geoforum, 44(3): 82-92.

Koettl, J. (2009) Human Trafficking, Modern Day Slavery, and Economic Exploitation. Social Protection and Labour, SP Discussion Paper, No. 0911. Geneva: The World Bank.

LeBaron, G. (2015) Unfree Labour Beyond Binaries. International Feminist Joumal of Politics, 17(1): 1-19.

LeBaron, G. and Phillips, N. (2018) States and the Political Economy of Unfree Labour. New Political Economy, 24(1): 1-21.

Lefebvre, H. (1991). The Production of Space. Oxford: Blackwell.

Lerche, J. (2007). A Global Alliance against Forced Labour? Unfree Labour, Neoliberal Globalization and the International Labour Organization. Journal of Agrarian Change, 7(4): 425-452.

Lucassen, J. (1997) Free and Unfree Labour Before the Twentieth Century: A Brief Overview In Free and Unfree Labour: The Debate Continues, edited by T. Brass and M. van der Linden. Berlin: Lang.

Mantouvalou, V. (2018) The Legal Construction of Exploitation. In Philosophical Foundations of Labour Law, edited by H. Collins, G. Lester and V. Mantouvalou. Oxford: Oxford University Press.

Marshall, T H. (1950) Citizenship and Social Class, and Other Essays. Cambridge: Cambridge University Press.

Marx, K. (1990) Capital, Volume 1. Trans. B. Fowkes. New York: Penguin.

McGrath, S. (2013) Many Chains to Break: The Multi-dimensional Concept of Slave Labour in Brazil. Antipode, 45(4): 1005-1028.

McGrath, S. and K. Strauss (2015) Unfreedom and Workers' Power: Ever-present Possibilities. In Handbook of the International Political Economy of Production, edited by K. van der Pijl. Cheltenham, UK: Edward Elgar.

McGrath, S. and S. Watson (2018) Anti-slavery as Development: A Global Politics of Rescue. Geoforum, 93: 22-31.

Mezzadri, A. (2016) Class, Gender and the Sweatshop. Third World Quarterly, 37(1): 1877-1900.

Mezzadri, S. and B. Neilson (2013) Border as Method, or, the Multiplication of Labor. Durham and London: Duke University Press.

Miles, R (1987) Capitalism and Unfree Labour: Anomaly or Necessity? London: Tavistock.

Miller, J.C. (2012) The Problem of Slavery as History: A Global Approach. New Haven and London: Yale University Press.

Morgan, J. and W. Olsen (2014) Forced and Unfree Labour: An Analysis. International Critical Thought, 4(1): $21-37$.

Nakano Glenn, E. (2002) Unequal Freedom: How Race and Gender Shaped American Citizenship and Labour. Cambridge, MS: Harvard University Press.

Newsome, K., P. Taylor, J. Bair and A. Rainnie (2015) Putting Labour in its Place. New York: Palgrave Macmillan.

O'Connell-Davidson, J. (2015) The Margins of Modern Slavery. Basingstoke: Palgrave Macmillan.

Pateman, C. (1988) The Sexual Contract. Cambridge: Polity Press.

Peksen, D., S.L. Blanton and R.G. Blanton (2017) Neoliberal Policies and Human Trafficking for Labor: Free Markets, Unfree workers? Political Research Quarterly, 70(3): 673-686.

Phillips, N. and F. Mieres (2015) The Governance of Forced Labour in the Global Economy. Globalizations, 12(2): 244-260.

Plant, R. (2017) Combatting Trafficking for Labour Exploitation in the Global Economy: The Need for a Differentiated Approach. In Revising the Law and Governance of Trafficking, Forced Labour and Modern Slavery, edited by P. Kotiswaran. Cambridge: Cambridge University Press. 
Polanco, G. (2016) Consent behind the Counter: Aspiring Citizens and Labour Control under Precarious (Im)Migration regimes. Third World Quarterly, 37(6): 1332-1350.

Rogaly, B. (2008) Migrant Workers and the ILO's Global Alliance against Forced Labour: A Critical Appraisal. Third World Quarterly, 29(7): 1431-1447.

Satzewich. V. (1991) Racism and the Incorporation of Foreign Labour: Farm Labour Migration to Canada. New York: Routledge.

Seccombe, W. (1992) A Millennium of Family Change. London: Verso.

Sharma, N. (2006) Home Economics: Nationalism and the Making of "Migrant Workers" in Canada. Toronto: University of Toronto Press.

Skrivankova, K. (2010) Between Decent Work and Forced Labour: Examining the Continuum of Exploitation. York: Joseph Rowntree Foundation.

Smith, A, (1983) The Wealth of Nations. London. Penguin.

Smith, A. (2015) Troubling "Project Canada": The Caribbean and the Making of "Unfree Migrant Labour". Canadian Journal of Latin American and Caribbean Studies, 40(2): 274-293.

Smith, A. and A. Choudry (2016) Introduction: Struggling against Unfree Labour. In Unfree Labour? Struggles of Migrant and Immigrant Workers in Canada, edited by A. Smith. and A. Choudry. San Francisco, CA: PM Press.

Steinfeld, R. (2001) Coercion, Contract, and Free Labor in the Nineteenth Century. Cambridge: Cambridge University Press.

Steinfeld, R. (2009) Coercion/Consent in Labour. WP-09-66 Centre on Migration, Policy and Society, Working Paper No. 66, University of Oxford, COMPAS.

Steinfeld, R. and Engerman, S. (1997) Labour - Free and Coerced? A Historical Reassessment of Differences and Similarities. In: Free and Unfree Labour: The Debate Continues, edited by T. Brass and M. van der Linden. Berlin: Lang.

Strauss, K. and J. Fudge (2014) Temporary Work, Agencies, and Unfree Labor: Insecurity in the New World of Work. In Temporary Work, Agencies, and Unfree Labor: Insecurity in the New World of Work, edited by J. Fudge and K. Strauss. New York: Routledge.

Strauss, K. and S. McGrath (2017) Temporary Migration, Precarious Employment and Unfree Labour Relations: Exploring the "Continuum of Exploitation" in Canada's Temporary Foreign Worker Program. Geoforum, 78(2): 199-208.

Tomlins, C. (2010) Freedom Bound: Law, Labor and Civic Identify in Colonizing English America, 1580-1865. New York: Cambridge University Press.

United Nations General Assembly (2000) Protocol to Prevent, Suppress and Punish Trafficking in Persons, Especially Women and Children, Supplementing the United Nations Convention against Transnational Organized Crime. UN Doc A/RES/55/25. New York: UN.

Van der Linden, M. (1997) The Origins, Spread and Normalization of Free Wage Labour. In Free and Unfree Labour: The Debate Continues edited by T. Brass and M. van der Linden M.). Berlin: Lang.

Yea, S. and S. Chok (2018) Unfreedom Unbound: Developing a Cumulative Approach to Understanding Unfree Labour in Singapore. Work, Employment and Society, 32(5): 925-941.

\section{BIOGRAPHICAL DETAILS}

JUDY FUDGE is a professor in the School of Labour Studies at McMaster University. She wrote this piece while she was a guest of the Director of Re:work: Work and Human Life Cycle in Global History, International Research Centre, Humboldt University, Berlin, from December 2017 to August 2018. [Email: fudgej@mcmaster.ca] 